\title{
Quorum sensing in Enterococcus faecium, Enterococcus faecalis and Bacillus cereus strains isolated from ricotta processing
}

\author{
Meg da Silva Fernandes ${ }^{1^{*}}$ Luciana Maria Ramires Esper ${ }^{2}$ Dirce Yorika Kabuki ${ }^{3}$ \\ Arnaldo Yoshiteru Kuaye ${ }^{1}$
}

${ }^{1}$ Departamento de Tecnologia de Alimentos, Universidade Estadual de Campinas (UNICAMP), Rua Monteiro Lobato, 80, 13083-862, Cidade Universitária Zeferino Vaz, Campinas, SP, Brasil. E-mail: megsfernandes@gmail.com. *Corresponding author.

${ }^{2}$ Departamento de Bromatologia, Universidade Federal Fluminense (UFF), Santa Rosa, Niteroi, RJ, Brasil.

${ }^{3}$ Departamento de Ciência de Alimentos, Universidade Estadual de Campinas (UNICAMP), Campinas, SP, Brasil.

\begin{abstract}
The quorum sensing phenomenon is a process of intra-and inter-species microbial communication involving the production and detection of extracellular signaling molecules. The autoinducer AI-2 has been proposed to serve as a 'universal signal'for interspecies communication. This study aimed to evaluate the capability of Enterococcus faecium, Enterococcus faecalis, and Bacillus cereus strains isolated from ricotta processing to produce quorum sensing signalling molecules (AI-2). The strains were evaluated for the presence of the luxS gene using the polymerase chain reaction. AI-2 quorum sensing signalling molecules were measured in relative light units (RLUs) using a luminometer. A total of $74 \%$ of E. faecium, $91 \%$ of E. faecalis, and $95 \%$ of $B$. cereus isolates were positive for lux $S$ gene. In addition, the induced bioluminescence in Vibrio harveyi BB170 was observed in all strains, indicating the presence of the AI-2 autoinducer.

Key words: luxS, AI-2, Vibrio harveyi, bioluminescence, Enterococcus spp., Bacillus cereus.
\end{abstract}

Quorum sensing em cepas de Enterococcus faecium, Enterococcus faecalis e Bacillus cereus isoladas do processamento de ricota

RESUMO: O fenômeno quorum sensing corresponde a um processo de comunicação intra e interespécies microbianas e é mediado por sinais químicos extracelulares, denominados moléculas sinalizadoras ou auto indutoras (AI). A molécula AI2 está envolvida na comunicação interespécies, denominada sistema "universal" de comunicação. Este estudo teve como objetivo avaliar a capacidade de Enterococcus faecium, Enterococcus faecalis e Bacillus cereus isolados do processamento de ricota em produzir moléculas sinalizadoras de Quorum sensing (AI-2). $O s$ isolados foram avaliados quanto à presença do gene luxS utilizando a reação em cadeia da polimerase (PCR). As moléculas sinalizadoras (AI-2) foram medidas em unidades relativas de luz (RLU) através de um luminometro. Um total de 74\% dos isolados de E. faecium, $91 \%$ de E. faecalis e 95\% de B. cereus foram positivos para o gene luxS. Além disso, todos os isolados apresentaram capacidade de induzir o fenômeno de bioluminescência em Vibrio harveyi BB170, indicando a presença de auto indutores AI-2.

Palavras-chave: luxS, AI-2, Vibrio harveyi, bioluminescência, Enterococcus spp., Bacillus cereus.

Quorum sensing phenomenon is a process of intra- and inter-species microbial communication and it is measured by extracellular chemical signals known as signal molecules or autoinducers (AI) (READING \& SPERANDIO, 2006). These molecules are produced by bacteria during their growth and are released into the environment. The extracellular accumulation of these signals indicates the presence of a relatively dense population, leading the bacteria to initiate a coordinated behavior (GRIFFITHS, 2005). This mechanism allows cells to control many of their functions, including virulence gene expression, plasmid transfer, toxin production, exopolysaccharide production and sporulation, and biofilm formation. Many bacteria, including various clinically important pathogens can use a molecule denominated as the autoinducer AI-2 for intercellular communication (BASSLER, 2002).

This study aimed to evaluate the capability of E. faecium, E. faecalis, and B. cereus strains isolated from ricotta processing to produce quorum sensing signalling molecules (AI-2). In total, 53 E. faecium isolates (43 from ricotta and 10 from environmental surfaces), 46 E. faecalis isolates (22 from ricotta, 12 from raw milk, 1 from cheese whey, and 11 from environmental surfaces) (FERNANDES et al., 2015a), and 38 B. cereus isolates (1 from raw milk, 2 from pasteurized milk, 2 from cheese whey, 18 from ricotta, and 15 from environmental surfaces) (FERNANDES et al., 2014) were evaluated in regards 
to the $\operatorname{luxS}$ gene. All strains were characterized in our previous studies as pathogenic, because they have virulence genes and are resistant to different antimicrobials. For more details, see FERNANDES et al. (2014) and FERNANDES et al. (2015a).

Table 1 shows the primers (Invitrogen, Life Technologies, Carlsbad, USA) used for amplification of the $\operatorname{lux} S$ gene. Primers were designed for luxS gene identification based on the sequences of E. faecalis ATCC 29212, E. faecium ATCC 51299 and B. cereus ATCC 14579, which are deposited in GenBank at the National Center for Biotechnology Information (NCBI) in Fasta format (GenBank access number 004722). Genomic DNA from pure cultures was extracted according to the methods described by FURRER et al. (1991). The PCR mixture (25 $\mu \mathrm{l}$ final volume) contained $0.2 \mu \mathrm{l}$ of Taq polymerase (Invitrogen, Life Technologies, Carlsbad, USA) (1 U/ $\mu \mathrm{l}), 2.5 \mu \mathrm{l}$ of $10 \mathrm{X}$ buffer (Invitrogen, Life Technologies, Carlsbad, USA) (200mM Tris $\mathrm{HCl} \mathrm{pH}$ $8.0,500 \mathrm{mM} \mathrm{KCl}), 1.5 \mu$ of $50 \mathrm{mM} \mathrm{MgCl}_{2}$ (Invitrogen, Life Technologies, Carlsbad, USA), $0.5 \mu$ l of $10 \mathrm{mM}$ dNTPs (Invitrogen, Life Technologies, Carlsbad, USA), $1 \mu \mathrm{l}(12.5 \mathrm{mM})$ of each primer, $1 \mu \mathrm{l}$ of extracted DNA and sterile Milli-Q water. Thermocycler parameters were as follows: an initial cycle of $94^{\circ} \mathrm{C}$ for $3 \mathrm{~min}, 35$ cycles of $94^{\circ} \mathrm{C}$ for $30 \mathrm{sec}, 60^{\circ} \mathrm{C}$ for $1 \mathrm{~min}$ and $72^{\circ} \mathrm{C}$ for $1.5 \mathrm{~min}$, a final extension step of $72^{\circ} \mathrm{C}$ for $7 \mathrm{~min}$ and then holding at $4^{\circ} \mathrm{C}$. Electrophoresis of the PCR products was performed on $1.5 \%$ agarose gels (Invitrogen, Life Technologies, EUA), which were stained with ethidium bromide. Visualization of the PCR products was performed using a UV transilluminator. The E. faecalis ATCC 29212, E. faecalis ATCC 51299, and B. cereus ATCC 14579 were utilized as positive control. As negative control, sterile Milli-Q water was used.

Biofilms are composed of aggregated cells and, consequently, they become a suitable environment for the quorum sensing phenomenon (BASSLER,
2002). Therefore, we selected 4 E. faecium strains, 4 E. faecalis strains, and $4 \mathrm{~B}$. cereus strains from the previously mentioned strains for detection of the AI-2 signalling molecules. These strains are known to be able of forming biofilm on stainless steel surfaces in our previous studies (FERNANDES et al., 2014; FERNANDES et al., 2015b).

All assays were performed in triplicate, according to TAGA \& XAVIER (2011). The strains were activated in Luria-Bertani (LB) broth (Difco, Becton, Dickinson and Company) supplemented with $0.5 \%$ glucose with continuous stirring at 175 $\mathrm{rpm}$ and $30^{\circ} \mathrm{C}$ for $24 \mathrm{~h}$. Cultures were then diluted 1:100 in LB broth (supplemented with $0.5 \%$ glucose) and incubated again for 6 hours (to mid-exponential phase) under the same conditions. Aliquots $(1 \mathrm{~mL})$ of bacterial culture were transferred to Eppendorf ${ }^{\circledR}$ tubes and centrifuged (Eppendorf® Centrifuge $5415 \mathrm{D}$, Hamburg, Germany) at $15000 \mathrm{x} \mathrm{g}$ for $5 \mathrm{~min}$. The supernatants were filtered through a $0.22-\mu \mathrm{m}$ membrane $\left(\right.$ Millex $^{\circledR}$ GV, Merck Millipore Ltd., Co. Cork, Ireland), and the filtered samples were immediately subjected to the assay. The $V$. harveyi BB170 biosensor was activated in Autoinducer Bioassay (AB) medium (SURETTE \& BASSLER, 1998 ) and incubated at $30^{\circ} \mathrm{C}$ for $16 \mathrm{~h}$ with continuous stirring at $175 \mathrm{rpm}$. The culture was then diluted 1:5000 in AB medium. The strains Salmonella Typhimurium ATCC 14028 and Escherichia coli O157:H7 were used as positive controls. As negative controls, sterile $\mathrm{AB}$ and LB culture media were used (TAGA \& XAVIER, 2011). For detection of AI-2, $10 \mu \mathrm{l}$ of filtered culture supernatant and $90 \mu \mathrm{l}$ of the $V$. harveyi $\mathrm{BB} 170$ dilution were combined in microwell plates (Greiner Bio One $\mathrm{GmbH}$, Frickenhausen, Germany). Plates were incubated at $30^{\circ} \mathrm{C}$ with continuous stirring at $300 \mathrm{rpm}$, and bioluminescent activity was measured in relative light units (RLU) using a luminometer (FLUOstar Omega Microplate Reader, BMG Labtech, Offenburg, Germany) at

Table 1 - Primer sequences used to detect the luxS gene.

\begin{tabular}{lrcc}
\hline Microorganism & Sequence of oligonucleotides (5' to 3') & Product size $(\mathrm{pb})$ & Reference \\
\hline E. faecalis & $\begin{array}{r}\text { CACCATATGTTCGCCTTGCT } \\
\text { ATAAAAACCAGTGCGGCAAC }\end{array}$ & 203 & Present study $^{*}$ \\
\hline E. faecium & $\begin{array}{l}\text { GAGCACTTGACTGCCGAACT } \\
\text { GCCACATTGTGTTCATTGC }\end{array}$ & 198 & Present study $^{*}$ \\
B. cereus & $\begin{array}{c}\text { CCCTTTCACAGGCAGTTTC } \\
\text { GATCATACGATTGTAAAGGCACC }\end{array}$ & 450 & Present study $^{*}$ \\
\hline
\end{tabular}

"GenBank access number: 004722. 
$15 \mathrm{~min}$ intervals for at least 5 hours. All assays were performed in triplicate, and the results correspond to the induction of bioluminescence as determined by the following equation.

Eq. 1:

Induction of bioluminescence $=$ RLU of the sample/ RLU of negative control.

Possible cell-to-cell communication between the E. faecium, E. faecalis, and B. cereus was evidenced by the presence of the luxS gene and by a positive bioluminescence reaction. Of the 53 E. faecium isolates, $74 \%$ (39) were positive for the luxS gene. Among them, 68\% (29/43) of the ricotta isolates were positive for the luxS gene, while $100 \%$ $(10 / 10)$ of the isolates from the environment were positive for this gene. For E. faecalis, 91\% (42/46) of the isolates were positive for the $\operatorname{luxS}$ gene. All raw milk (12/12) and cheese whey (1/1) samples contained the $\operatorname{luxS}$ gene, and $90 \%$ (10/11) of samples from the environment and $86 \%(19 / 22)$ of ricotta samples were positive for this gene. Additionally, $95 \%(36 / 38)$ of the $B$. cereus isolates were positive for the $\operatorname{lux} S$, while all isolates from ricotta $(18 / 18)$ and raw (1/1) and pasteurised milk (2/2) were positive for this gene. Furthermore, 94\% (14/15) of isolates from the environment and 50\% (1/2) of isolates from cheese whey were also positive for the luxS gene. Therefore, this study proves the existence of the luxS gene in E. faecium, E. faecalis and B. cereus strains isolated from various locations, ranging from the raw material to the final product. The majority of $B$. cereus, E. faecalis, and E. faecium strains presented the luxS, demonstrating the possibility of producing the Al-2 autoinducer (XAVIER \& BASSLER, 2003). The autoinducer AI-2 is synthesized by the enzyme luxS, which is involved in the metabolism of S-adenosylmethionine (SAM), converting it into ribosylhomocysteine S-homocysteine (SRH) and 4,5-dihydroxy-2,3-pentanedione (DPD). The DPD is a very unstable compound that reacts with water and cyclizes to form several furanones, one of which is thought to be the precursor of AI-2 (SCHAUDER et al., 2001). Results indicating the presence of the Al-2 quorum sensing signaling molecules by detecting the presence of the luxS gene were corroborated by confirmation of the capacity to induce the phenomenon of bioluminescence in $V$. harveyi BB170. Normalized relative light unit (RLU) levels ranging from 0.89 to 1.59 , were obtained. According to figure 1, E.

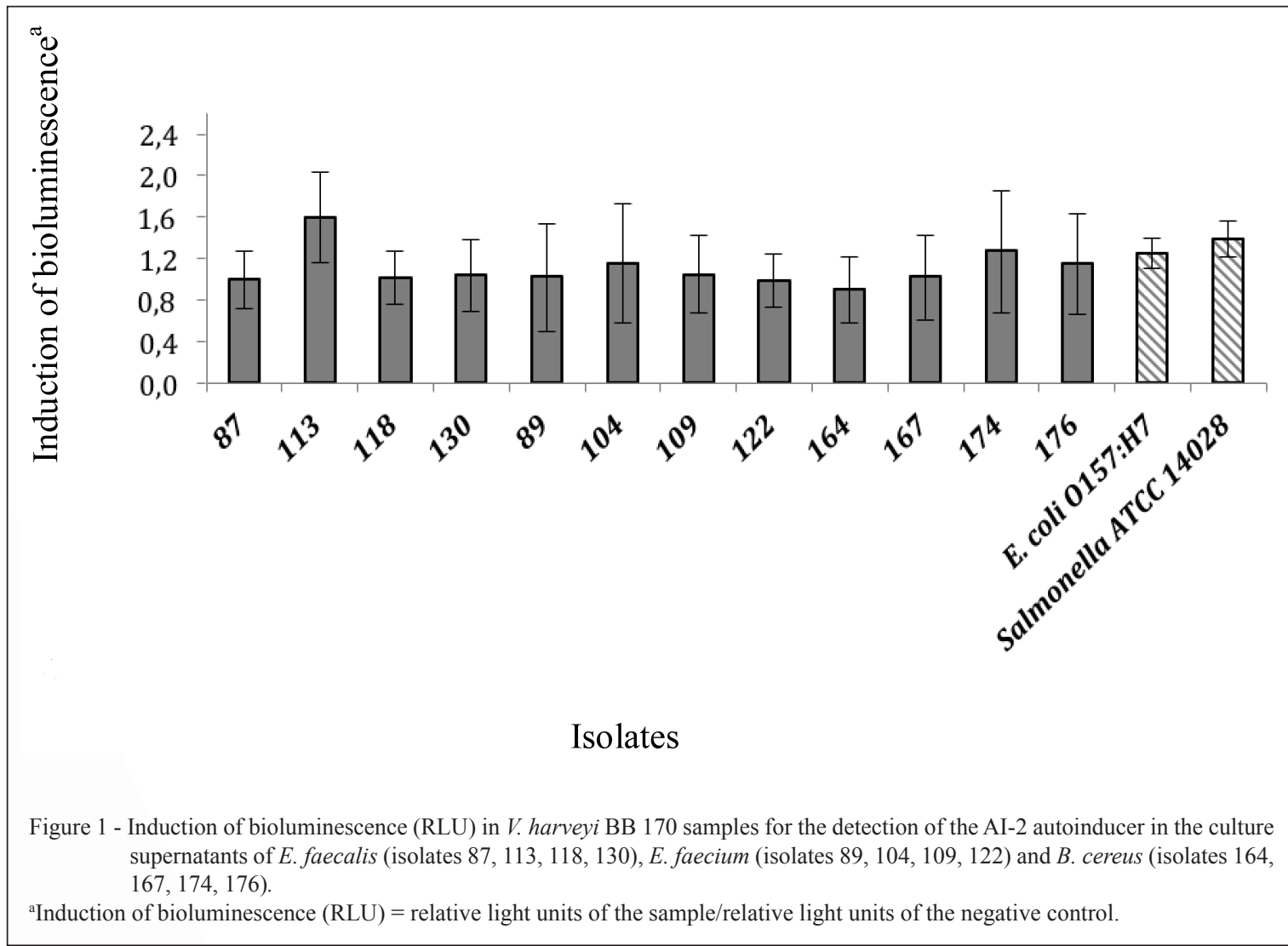

Ciência Rural, v.48, n.2, 2018. 
faecalis isolate 113 and $B$. cereus isolate 174 stood out for showing the highest induction activity as compared to the other samples tested. These results are in accordance with TAGA \& XAVIER (2011), whose reported a bioluminescence induction index of 1.8 after a 6 -h culture of $S$. Typhimurium. When calculating AI-2 activity, the possible presences of AI-2 exogenous molecules (produced by the test strains) and of AI-2 endogenous molecules (produced by $V$. harveyi) have been taken into consideration. Endogenous AI-2 was not a target of this study but could cause an error in interpretation, since after a few hours, an accumulation of endogenous AI-2 can occur due to the increase in the population of $V$. harveyi $\mathrm{BB} 170$, inducing bioluminescence once again. Thus, when calculating AI-2 activity, the light was measured the instant immediately prior to the start of light production by $V$. harveyi (TAGA \& XAVIER, 2011). In this study, the 5-h time point was selected to monitor the effects of exogenous AI-2 (SHAO et al., 2012). Confirmation of the presence of the luxS gene associated with a positive response for the phenomenon of bioluminescence with $V$. harveyi BB170 for most isolates tested in this study, corroborates with the hypothesis of the presence of the AI-2 autoinducer and the existence of the phenomenon of quorum sensing. This phenomenon may favor the adaptation and survival of microorganisms in both food and biofilms. The $E$. faecium, E. faecalis and B. cereus strains analyzed in this study are able of forming biofilm. According to SHAO et al. (2012) and AUGER et al. (2006), AI-2 has an important role in biofilm formation by E. faecalis and B. cereus, respectively. AUGER et al. (2006) showed that an increase in the level of AI-2 in the medium resulted in a decrease in the density of the biofilm formed by $B$. cereus. This result indicated that the presence of AI- 2 can also cause the detachment of a large proportion of the cells in the biofilm. Cells detachment or parts of biofilms may lead to the contamination of the food or to the colonization of other regions, resulting in new biofilms (SIMÕES et al., 2010). These facts indicated that AI-2 may be related to the regulation of important phenotypes in food contamination. Further research should be conducted to promote understanding of the way bacteria communicate. The knowledge of the mechanisms of survival and interaction of microorganisms in a biofilm and its relation with the quorum sensing system can help in the development of measures of control and elimination of these biofilms in the food processing environment, providing food safety.

\section{ACKNOWLEDGMENTS}

This research was supported by the Fundação de Amparo à Pesquisa do Estado de São Paulo (FAPESP) - Process n.2010/10507-7. The authors are grateful to prof. Dr. Geraldo Renato de Paula (UFF) for his aid in designing the primers and to prof. Dr. Maristela da Silva Nascimento (UNICAMP) for donating the culture of $B$. cereus ATCC 14579.

\section{REFERENCES}

AUGER, S.; et al. Autoinducer 2 affects biofilm formation by Bacillus cereus. Applied and Environmental Microbiology, v.72, p.937-941, 2006. Available from: <https://www.ncbi.nlm. nih.gov/pmc/articles/PMC1352198/>. Accessed: dez. 18, 2017. doi: 10.1128/AEM.72.1.937-941.2006.

BASSLER, B.L. Small talk. Cell-to-cell communication in bacteria. Cell, v.109, p.421-424, 2002. Available from: <http:// www.sciencedirect.com/science/article/pii/S0092867402007493>. Accessed: dez. 18, 2017. doi: 10.1016/S0092-8674(02)00749-3.

FERNANDES, M.S.; et al. Enterotoxigenic profile, antimicrobial susceptibility, and biofilm formation of Bacillus cereus isolated from ricotta processing. International Dairy Journal, v.38, p.16-23, 2014. Available from: <https:/www.sciencedirect.com/ science/journal/09586946/38/1>. Accessed: dez. 18, 2017. doi: 10.1016/j.idairyj.2014.03.009.

FERNANDES, M.S.; et al. Dissemination of Enterococcus faecalis and Enterococcus faecium in a Ricotta Processing Plant and Evaluation of Pathogenic and Antibiotic Resistance Profiles. Journal of Food Science, v.80, p.M765-M775, 2015a. Available from: $<$ https://www. ncbi.nlm.nih.gov/pubmed/25874819>. Accessed: dez. 18, 2017. doi: 10.1111/1750-3841.12824.

FERNANDES, M.S., et al. Biofilms of Enterococcus faecalis and Enterococcus faecium isolated from the processing of ricotta and the control of these pathogens through cleaning and sanitization procedures. International Journal of Food Microbiology, v.200, p.97-103, 2015b. Available from: <https://www.ncbi.nlm.nih.gov/ pubmed/25702883>. Accessed: dez. 18, 2017. doi: 10.1016/j. ijfoodmicro.2015.02.004.

FURRER,B; etal. Detection and identification of Listeriamonocytogenes in cooked sausage products and in milk by in vitro amplification of hemolysis gene fragments. Journal of Applied Bacteriology, v.70, p.372-379, 1991. Available from: <http://onlinelibrary.wiley.com/ doi/10.1111/j.1365-2672.1991.tb02951.x/epdf>. Accessed: dez. 19, 2017. doi:10.1111/j.1365-2672.1991.tb02951.x/epdf.

GRIFFITHS, M. Quorum sensing. In: GRIFFITHS, M. Understanding pathogen behavior: virulence, stress response and resistance. England: CRC Press, 2005, p.580-640.

READING, N.C.; et al. Quorum sensing: the many languages of bacteria. FEMS Microbiology Letters, v.254, p.1-11, 2006. Available from: <https://academic.oup.com/femsle/ article/254/1/1/640226>. Accessed: dez. 18, 2017. doi: 10.1111/j.1574-6968.2005.00001.x.

SCHAUDER, S.; et al. The LuxS family of bacterial autoinducers: biosynthesis of a novel quorum sensing signal molecule. Molecular Microbiology, v.41, p.463-476, 2001. Available from: <http:// onlinelibrary.wiley.com/doi/10.1046/j.1365-2958.2001.02532.x/ 
full>. Accessed: dez. 18, 2017. doi: 10.1046/j.13652958.2001.02532.x.

SHAO, C., et al. LuxS-Dependent AI2 Regulates Versatile Functions in Enterococcus faecalis V583. Journal of Proteome Research, v.11, p.4465-4475, 2012. Available from: $<$ http://pubs. acs.org/doi/ipdf/10.1021/pr3002244>. Accessed: dez. 18, 2017 doi: $10.1021 / \mathrm{pr} 3002244$.

SIMÕES, M.; et al. A review of current and emergent biofilm control strategies. LWT - Food Science and Technology, v.43, p.573-583, 2010. Available from: <https://www.sciencedirect. com/science/journal/00236438/43/4>. Accessed: dez.19, 2017. doi: 10.1016/j.lwt.2009.12.008.

SURETTE, M.G., BASSLER, B.L. Quorum sensing in Escherichia coli and Salmonella Typhimurium. Proceedings of the National Academy of Sciences of the United States of America, v.995, p.7046-50, 1998. Available from: <http://www. pnas.org/content/95/12/7046.full.pdf?sid=9af5ac7f-55b4-42518d65-228893d95f92>. Accessed: dez. 19, 2017.

TAGA, M.E.; XAVIER, K.B. Methods for analysis of bacterial autoinducer-2 production. Current Protocols in Microbiology, v.23, p.1-15, 2011. Available from: <http://onlinelibrary.wiley. com/doi/10.1002/9780471729259.mc01c01s23/pdf>. Accessed: dez. 19, 2017. doi: 10.1002/9780471729259.

XAVIER, K.B.; BASSLER, B.L. LuxS quorum sensing: more than just a numbers game. Current Opinion in Microbiology, v.6, p.191-197, 2003. Available from: $<$ https://www.sciencedirect.com/science/article/pii/ S1369527403000286\#>. Accessed: dez. 19/2017. doi: 10.1016/S369-5274(03)00028-6. 